\title{
Studies on the Mechanism of Inhibition of Growth of Vibrio cholerae by Erythrose
}

\author{
By JAYASREE NATH* AND ASOKE G. DATTA \\ Physiology Department, Indian Institute of Experimental Medicine, \\ Calcutta-32, India
}

(Accepted for publication Io February 1970)

\section{SUMMARY}

Erythrose strongly inhibits the growth of Vibrio cholerae and Vibrio eltor. The inhibition can be reversed by washing the cells free from erythrose with sterile normal saline. The respiration of $V$. cholerae cells in the presence of glucose is markedly inhibited by erythrose but the oxygen uptake of cellfree extract under the same conditions is not affected. From the results of experiments on the uptake of $\left[{ }^{14} \mathrm{C}\right]$ glucose and $\left[\alpha-{ }^{14} \mathrm{C}\right]$ methylglucoside, it may be concluded that erythrose inhibits the transport of glucose across the cell membrane and thereby inhibits the growth of the organism.

\section{INTRODUCTION}

It has been reported (Roy Chowdhury \& Datta, I965) that erythrose has a marked inhibitory effect on the growth of Vibrio cholerae, when grown on synthetic medium containing glucose. This growth inhibitory effect of erythrose could be demonstrated even when glucose was replaced by different hexoses or pentoses. The growth inhibitory effect of erythrose was found to be proportional to the concentration of erythrose in the medium; it could also be demonstrated in experiments in vivo (Bhattacharya, Roy Chowdhury \& Datta, I965). This paper presents a more detailed biochemical study on the mechanism of this growth-inhibitory effect of erythrose.

\section{METHODS}

Organisms and media. Vibrio cholerae (Inaba type) or Vibrio eltor were grown for I $8 \mathrm{~h}$. at $37^{\circ}$ on a synthetic medium of Finkelstein \& Lankford (I955) containing glucose instead of sucrose, as the sole carbon source. Glucose was added aseptically, according to the concentration needed, as a $50 \%(\mathrm{w} / \mathrm{v})$ solution sterilized by steaming for three periods of half an hour each. Growth was assayed by measuring the turbidity increase in $18 \mathrm{~h}$. using a Klett Summerson photoelectric colorimeter at $540 \mathrm{~nm}$. For this purpose $50 \mathrm{ml}$. conical flasks, with optically matched sidearms to fit in the colorimeter, were used.

Respiration studies. The vibrios were grown on the synthetic medium and washed by centrifuging three times in cold normal saline $(\mathrm{pH} 7 \cdot 8)$. Oxygen consumption was measured in a Warburg apparatus by the conventional method (Umbreit, Burris \& Stauffer, 1959) at $37^{\circ}$ using air as the gas phase. The results have been corrected for endogenous respiration.

* Present address: Department of Biochemistry, University of Birmingham, Birmingham I 5 . 
Preparation of cell-free extract. The vibrios were grown in $500 \mathrm{ml}$. conical flasks containing $100 \mathrm{ml}$. of synthetic medium with the requisite amount of glucose, on a rotary shaker at $35^{\circ}$. Organisms from two to three flasks were pooled and washed three times in cold normal saline by centrifugation at $3500 \mathrm{~g}$ in a Sorvall refrigerated centrifuge. The packed cells were transferred to a chilled mortar with a minimal volume of cold $0.05 \mathrm{M}-\mathrm{K}$ phosphate buffer $(\mathrm{pH} 7.4)$ and homogenized with an equal weight of chilled glass-powder for I to $2 \mathrm{~min}$. The mixture was then extracted with a minimal volume of the same buffer, quickly transferred to a chilled centrifuge tube, and the glass powder and cell debris removed by centrifugation at $10,000 \mathrm{~g}$ for $10 \mathrm{~min}$. The resulting supernatant (cell-free extract) was dialysed for $2 \mathrm{~h}$. against deionized water and used for the respirometric experiments. The whole operation was carried out at 0 to $4^{\circ}$.

Assay of different enzymes. Undialysed cell-free extract of Vibrio cholerae, prepared as stated above, was used. Hexokinase (Racker, 1947), glucose-6-phosphate dehydrogenase (Kornberg \& Horecker, 1955) and phosphohexoseisomerase (Slein, I955) were assayed by measuring the increase in absorbance at $340 \mathrm{~nm}$. in a Zeiss spectrophotometer, using $\mathrm{I} \mathrm{cm}$. light-path cuvettes. Protein concentrations were estimated by the method of Lowry, Rosebrough, Farr \& Randall (I95I) with a bovine serum albumin (Sigma Chemicals) as standard.

$\left[{ }^{14} \mathrm{C}\right]$ Glucose uptake. Vibrio cholerae was grown overnight in synthetic medium, harvested in a refrigerated centrifuge, washed twice with five volumes of cold normal saline and finally suspended in two volumes of cold normal saline. Usually $0.5 \mathrm{ml}$. of this cell suspension $\left(0.25 \mathrm{~g}\right.$. organisms, wet wt) was incubated with $550 \mu$ moles of $\left[{ }^{14} \mathrm{C}\right]$ glucose $\left(36,000\right.$ counts $/ \mathrm{min}$.) at $37^{\circ}$ for $30 \mathrm{~min}$. either in the presence or absence of $50 \mu$ moles of erythrose. After incubation, the bacteria were washed three times with five volumes of cold normal saline and finally bacteria suspended in I ml. of distilled water: $0.5 \mathrm{ml}$. of this suspension was dried on an aluminium planchet by means of an infrared lamp for measurement of radioactive counts. In addition a suitable sample of the suspension was used for determination of the protein content.

$\left[\alpha_{-14} C\right]$ Methylglucoside. This radiochemical was prepared according to the method of Bollenback (1963) using uniformly labelled $\left[{ }^{14} \mathrm{C}\right]$ glucose and methanol in the presence of a cation exchange resin.

${ }^{14}$ Carbon counts were measured in a Tracer Lab Super scaler Gas-flow counter, Model SC I 8 A.

Chemicals. The following were obtained from Sigma: glycolaldehyde, erythrose, glyceraldehyde, sodium pyruvate, DL-glyceraldehyde-3-phosphate (diethyl acetal barium salt), glucose-6-phosphate, 6-phosphogluconate, ATP, NAD, NADP and tris (hydroxymethylaminomethane). Analar (British Drug Houses, Poole, England) glucose, 2,4-dinitrophenol (DNP) and erythritol were used in these experiments. Erythrose was obtained from L. Light \& Co., Colnbrook, England. D-Threose was kindly supplied by Dr Perlin, and erythrose-4-phosphate was a gift from Professor B. L. Horecker. $\left[{ }^{14} \mathrm{C}\right]$ Glucose (uniformly labelled) was supplied by the Bhabha Atomic Research Centre, India. 
RESULTS

\section{Inhibition of growth}

When it was observed that five- and six-carbon sugars did not inhibit the growth of Vibrio cholerae (Roy Chowdhury \& Datta, 1965), sugars of shorter carbon-chain length and their derivatives were tested using the same procedure as described earlier. They were particularly chosen to provide either terminal groups identical with those of erythrose, or only one terminal group similar to erythrose. The compounds tested were threose, erythritol, glyceraldehyde, glyceraldehyde-3-phosphate, erythrose-4phosphate and glycolaldehyde: all except erythritol inhibited growth (Table 1). The inhibitory compounds have the common characteristic of a free aldehyde group on the first carbon. Erythritol, in contrast to the rest of the compounds, does not have this reducing group on the first carbon and it may be noted that it did not produce any inhibitory effect on the growth of $V$. cholerae. Erythrose similarly inhibited the growth of $V$. eltor, the causative organism of a closely related disease to cholera. Under the same experimental conditions as described in Table $\mathrm{I}$, the turbidity change due to growth of $V$. eltor with glucose as sole carbon source was 300 whereas in presence of glucose and erythrose the turbidity change was only 20.

Since the experiments in vivo (Bhattacharya et al. 1965) indicated that erythrose is only vibriostatic and not vibriocidal, an attempt was made to study the same phenomenon in vitro. The inhibitory effect of erythrose was found to be a reversible process and could be removed by merely washing the vibrios. When the organisms were incubated in synthetic medium containing erythrose, no turbidity increase occurred in I $8 \mathrm{~h}$. If these inhibited vibrios were centrifuged, washed aseptically three times in sterile normal saline and then transferred to fresh medium containing glucose, growth occurred during the next $18 \mathrm{~h}$. The increase in turbidity was similar to that of organisms which had not been exposed to erythrose. This alternate inhibition and restoration of growth after washing could be repeated at least three successive times with the same culture.

Growth of Vibrio cholerae on peptone broth medium instead of the synthetic medium was not inhibited by erythrose, and the addition of a mixture of 20 amino acids to the synthetic medium completely prevented inhibition by erythrose. Cysteine alone could reverse the inhibitory effect of erythrose but could not support the growth of the organism when added as sole carbon source (Table 2). Cysteine, by itself, has very little effect on the growth of $V$. cholerae.

The growth-inhibitory effect was thus specific for the aldehyde group at the carbon-one position of the sugar molecule; it was not bactericidal and could be removed by washing the organisms.

\section{Inhibition of glucose metabolism}

The glucose respiration of non-dividing Vibrio cholerae was almost completely inhibited in the presence of erythrose (Fig. I). Although there was a small oxygen consumption with erythrose alone as substrate, the oxygen consumption was almost nil when both glucose and erythrose were added together. With cell-free extracts of $V$. cholerae using glucose as substrate, however, there was no appreciable inhibition in the presence of erythrose (Fig. 2). Attempts to abolish the initial lag in the uptake of oxygen by the addition of ATP and almost all the known cofactors were unsuccessful. When 
Table I. Effect of sugars and sugar derivatives on the growth of Vibrio cholerae

The increase in turbidity (in Klett units) was determined after $18 \mathrm{~h}$. incubation at $37^{\circ}$ in $\mathrm{roml}$. synthetic medium $+550 \mu$ moles glucose $+50 \mu$ moles of additional sugar or derivative.

$\begin{array}{lc}\text { Slucose } & \begin{array}{c}\text { Turbidity } \\ \text { increase }\end{array} \\ \text { Glucose + erythrose } & 200 \\ \text { Glucose + threose } & 0 \\ \text { Glucose + glyceraldehyde } & 0 \\ \text { Glucose + erythrose-4-phosphate } & 0 \\ \text { Glucose + glyceraldehyde-3-phosphate } & 0 \\ \text { Glucose + erythritol } & 0\end{array}$

Table 2. Effect of cysteine on the growth inhibitory effect of erythrose on Vibrio cholerae

Turbidity change (in Klett units) determined after $18 \mathrm{~h}$. at $37^{\circ}$ in $10 \mathrm{ml}$. synthetic medium $+550 \mu$ moles glucose; cysteine and erythrose ( $50 \mu$ moles of each) added as indicated.

\begin{tabular}{lc}
\multicolumn{1}{c}{ System } & $\begin{array}{c}\text { Turbidity } \\
\text { increase }\end{array}$ \\
Glucose & 198 \\
Glucose+ cysteine & 210 \\
Glucose + erythrose & 0 \\
Glucose + erythrose+cysteine & I95 \\
Cysteine & 45
\end{tabular}

6-phosphogluconate and pyruvate, the primary reactants of the hexose monophosphate shunt pathway and the tricarboxylic acid cycle, were used as substrates, oxygen uptake by cell-free extract was also not inhibited by erythrose.

It has been reported by Racker, Klybas \& Schramm (1959) and Fluharty \& Ballou (I959) that D-threose 2,4-diphosphate strongly inhibits glyceraldehyde-3-phosphate dehydrogenase. Furthermore, Grazi, De Flora \& Pontremoli (I960) and subsequently Venkataraman \& Racker (196I) have shown that erythrose-4-phosphate strongly inhibits phosphohexose-isomerase. Hence studies were made with cell-free extract of Vibrio cholerae, in which the activities of certain enzymes were assayed spectrophotometrically in the presence and absence of erythrose. The activities of hexokinase, glucose-6-phosphate dehydrogenase, phosphohexoseisomerase and glyceraldehyde-3phosphate dehydrogenase were not inhibited significantly by erythrose.

Inhibition of oxygen consumption of whole cells by erythrose and failure to produce such inhibition in experiments with cell-free extracts led us to investigate the effect of erythrose on the uptake of glucose by whole cells.

\section{Uptake of glucose}

When Vibrio cholerae was grown overnight ( $18 \mathrm{~h}$.) in a synthetic medium in the presence and absence of erythrose together with $\left[{ }^{14} \mathrm{C}\right]$ glucose, parallel effects by erythrose on inhibition of growth and inhibition of $\left[{ }^{14} \mathrm{C}\right]$ glucose uptake were found (Table 3).

Since in this experiment glucose uptake by Vibrio cholerae cells was measured during an $\mathrm{I} 8 \mathrm{~h}$. growth period, with the possibility of glucose being metabolized during that long period of incubation, short-term incorporation studies were made using resting 


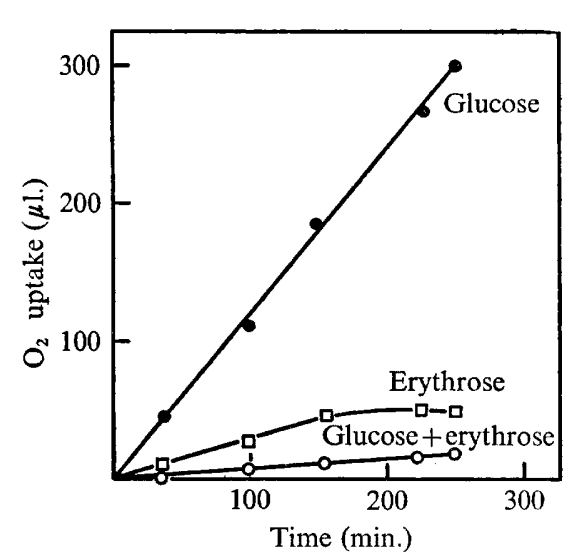

Fig. I

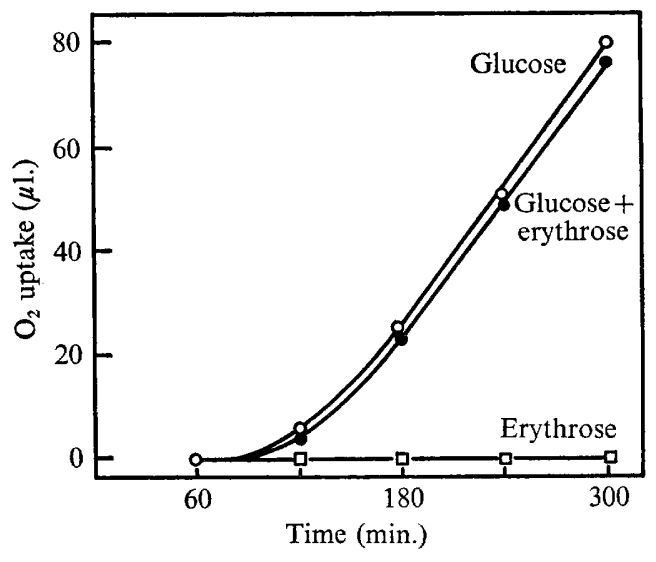

Fig. 2

Fig. I. Effect of erythrose on the oxygen uptake of non-dividing Vibrio cholerae. Final volume $3 \mathrm{ml}$, containing $150 \mu$ moles $\mathrm{K}$ phosphate buffer, $\mathrm{pH} 7.4$; $10 \mu$ moles glucose; I $\mu$ mole erythrose (where indicated) and $\mathrm{I} \cdot 0 \mathrm{ml}$. bacterial suspension $(6 \mathrm{mg}$. protein). The centre well contained $0.15 \mathrm{ml} .30 \% \mathrm{KOH}$. Gas phase, air; temp. $37^{\circ}$.

Fig. 2. Effect of erythrose on the oxygen uptake of cell-free extracts of Vibrio cholerae. Final volume $3 \mathrm{ml}$. containing $150 \mu$ moles $\mathrm{K}$ phosphate buffer, $\mathrm{pH} 7.4$; $10 \mu$ moles glucose; $3 \mu$ moles ATP; I $\mu$ mole erythrose and I.o ml. of cell-free extract ( $4.5 \mathrm{mg}$. protein). The centre well contained $0.15 \mathrm{ml}$. of $30 \% \mathrm{KOH}$. Gas phase, air; temp. $37^{\circ}$.

\section{Table 3. Effect of erythrose on $\left[{ }^{14} \mathrm{C}\right]$ glucose uptake during growth of Vibrio cholerae}

Flasks containing $560 \mu$ moles of unlabelled glucose, I $\mu \mathrm{Ci}$ of $\left[{ }^{14} \mathrm{C}\right]$ glucose and $50 \mu$ moles of erythrose (where required) in a final volume of $10 \mathrm{ml}$. synthetic medium were inoculated with $V$. cholerae and incubated at $37^{\circ}$ for $18 \mathrm{~h}$. Growth was measured in terms of increase in turbidity (Klett units). After $\mathrm{I} 8 \mathrm{~h}$. the organisms were washed twice with normal saline and once with distilled water, suspended in $1 \mathrm{ml}$. of distilled water and $0.5 \mathrm{ml}$. of this suspension used for counting the radioactivity. Protein was measured on the remaining suspension and the results are expressed as counts/min. mg. protein.

\begin{tabular}{|c|c|c|c|c|}
\hline \multirow[b]{2}{*}{ System } & \multicolumn{2}{|c|}{ Uptake of ${ }^{14} \mathrm{C}$} & \multicolumn{2}{|c|}{ Growth } \\
\hline & $\begin{array}{l}\text { counts/min./ } \\
\text { mg. protein }\end{array}$ & $\begin{array}{l}\text { Inhibition } \\
(\%)\end{array}$ & $\begin{array}{c}\text { Turbidity } \\
\text { increase in } 18 \mathrm{~h} .\end{array}$ & $\begin{array}{c}\text { Inhibition } \\
(\%)\end{array}$ \\
\hline Glucose & 1012 & - & I 45 & - \\
\hline Glucose + erythrose & 150 & 85 & 20 & 86 \\
\hline
\end{tabular}

suspensions of $V$. cholerae. The results in Table 4 confirm that erythrose effectively inhibited the uptake of $\left[{ }^{14} \mathrm{C}\right]$ glucose by $V$. cholerae. It may be recalled (see Table 2 ) that the inhibitory effect of erythrose on the growth of the organism was reversed by the addition of cysteine. From Table 4 it may be seen that the inhibition of $\left[{ }^{14} \mathrm{C}\right]$ glucose uptake by the $V$. cholerae in the presence of erythrose was also reversed by cysteine which was without effect in the absence of erythrose. Table 4 also shows that the inhibition of glucose uptake by 2,4-dinitrophenol was accentuated by erythrose.

Cohen \& Monod (I957) have shown that $\alpha$-methylglucoside, normally a non- 
metabolizable glucose derivative, is useful in the study of the glucose permeation mechanism in bacteria. When $\alpha$-methylglucoside was added to the synthetic medium in place of glucose, it did not support growth of Vibrio cholerae indicating that it is not measurably metabolized by the organism. The compound accumulated inside the cell, however, at a linear rate for $2 \mathrm{~h}$. (Fig. 3). Glucose at a concentration of $10^{-4} \mathrm{M}$ considerably inhibited the uptake of $\left[\alpha-{ }^{14} \mathrm{C}\right]$ methylglucoside (Fig. 3).

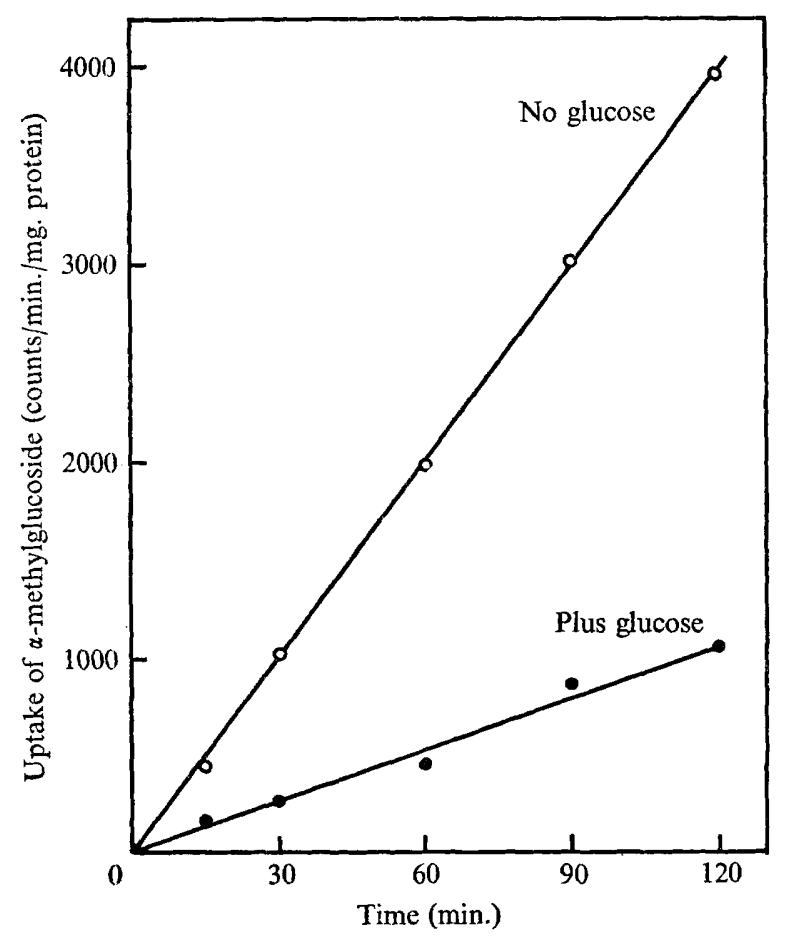

Fig. 3. Effect of glucose on the uptake of $\left[\alpha{ }^{14} \mathrm{C}\right]$ methylglucoside by Vibrio cholerae. Incubation mixture contained $0.5 \mathrm{ml}$. bacterial suspension, Io $\mu$ moles $\left[\alpha_{-}{ }^{14} \mathrm{C}\right]$ methylglucoside ( 1000 counts $/ \mathrm{min} . / \mu$ mole) and $0.1 \mu$ mole glucose in a final volume of $\mathrm{I} \cdot 0 \mathrm{ml}$. The reaction mixtures were incubated for different periods of time and uptake measured as Table 3 .

\section{Table 4. Effect of erythrose on the uptake of $\left[{ }^{14} \mathrm{C}\right]$ glucose by non-growing Vibrio cholerae}

The incubation mixture contained $550 \mu$ moles of $\left[{ }^{14} \mathrm{C}\right]$ glucose $(36,000$ total counts $/ \mathrm{min}$. $)$ and $0.5 \mathrm{ml}$. bacterial suspension in a final volume of $10 \mathrm{ml}$. normal saline with, where indicated, erythrose, $50 \mu$ moles; 2,4-dinitrophenol, $25 \mu$ moles; cysteine, Io $\mu$ moles. After $30 \mathrm{~min}$. incubation at $37^{\circ}$ the organisms were centrifuged, washed and treated as described in Table 3.

\section{System}

Glucose

Glucose + erythrose

Glucose $+2,4$-dinitrophenol

Glucose + 2,4-dinitrophenol + erythrose

Glucose + cysteine

Glucose + cysteine + erythrose
Uptake of ${ }^{14} \mathrm{C}$

(counts/min./ mg. protein)

3030

218

607

101

3010

2800 
To check whether $\left[\alpha^{14} \mathrm{C}\right]$ methylglucoside was transported intact into the bacteria, Vibrio cholerae was exposed to the glucoside and then collected by centrifugation. After washing twice with $5 \mathrm{ml}$. normal saline the packed organisms were extracted with $3 \times 5 \mathrm{ml}$. portions of hot water. The combined washings were concentrated to about $\mathrm{I} \cdot 0 \mathrm{ml}$. and $0.05 \mathrm{ml}$. samples were chromatographed on Whatman no. I filter paper using butanol:acetic acid: water $(60: 30: 10)$. Radioautograms of these extracts showed a single radioactive spot with and $R_{F}$ value identical to that of authentic $\alpha$-methylglucoside. Furthermore, $80 \%$ of the total radioactivity applied to the paper could be eluted from the $\alpha$-methylglucoside region and when co-chromatographed with authentic $\left[\alpha-{ }^{14} \mathrm{C}\right]$ methylglucoside gave one single radioactive spot. The above observations suggest that $\alpha$-methylglucoside was transported into $V$. cholerae as free $\alpha$-methylglucoside through the mediation of the permease responsible for the entry of glucose.

Table 5 shows that erythrose inhibited the uptake of $\left[\alpha^{14} \mathrm{C}\right]$ methylglucoside by Vibrio cholerae. Attempts were made to check whether the inhibition of $\alpha$-methylglucoside uptake by erythrose was of competitive nature by plotting the reciprocals

\section{Table 5. Effect of erythrose on the uptake of $\left[\alpha_{-}{ }^{14} C\right]$ methylglucoside by non-growing Vibrio cholerae}

The incubation mixture contained $0.5 \mathrm{ml}$. bacterial suspension, $10 \mu$ moles of $\left[\alpha-{ }^{14} \mathrm{C}\right]$ methylglucoside ( 1000 counts $/ \mathrm{min} . / \mu$ mole) in a final volume of $\mathrm{I} \cdot 0 \mathrm{ml}$. normal saline. Erythrose, I $\mu$ mole. Incubation for $30 \mathrm{~min}$. at $37^{\circ}$, and then the uptake of ${ }^{14} \mathrm{C}$ measured as in Table 3 .

$\begin{array}{lc}\text { System } & \begin{array}{c}\text { Uptake of }{ }^{14} \mathrm{C} \\ \text { (counts/min./ } \\ \text { mg. protein) }\end{array} \\ \alpha \text {-Methylglucoside } & 1058 \\ \alpha \text {-Methylglucoside }+ \text { erythrose } & 328\end{array}$

of the observed uptakes of $\alpha$-methylglucoside at different concentrations of the glucoside in the presence and absence of erythrose. Results of these experiments were erratic and no definite conclusion could be made.

\section{DISCUSSION}

The growth inhibitory effect described was dependent on the presence of a free terminal aldehyde group in a sugar molecule with a chain length of not more than four carbons: the lack of inhibition by pentoses or hexoses may be due to the fact that when in a ring form their aldehyde groups are masked.

The results indicate that erythrose does not inhibit any one of the major pathways of glucose catabolism (e.g. glycolytic, shunt pathway and tricarboxylic acid cycle) in cell-free extracts of Vibrio cholerae, whereas it does inhibit very strongly the oxygen uptake of whole organisms with glucose as substrate. This effect is explained by the marked inhibitory effect of erythrose on the uptake of $\left[{ }^{14} \mathrm{C}\right]$ glucose and $\left[\alpha-{ }^{14} \mathrm{C}\right]$ methylglucoside by $V$. cholerae, an effect demonstrable even with bacteria in the growth phase. Since transport of substrates across bacterial membranes is believed to be mediated by stereospecific proteins, or 'permeases' (Cohen \& Monod, 1957), the growth inhibitory effect of erythrose on $V$. cholerac might be on the 'gluco-permease' system. Such systems are likely to be depressed in the presence of a typical uncoupling agent 
like 2,4-dinitrophenol which markedly reduced the glucose uptake by non-growing organisms, and this inhibitory effect was increased by erythrose.

Results presented in Table 3 to 5 strongly suggest the inhibitory effect of erythrose to be on the transport of glucose across the bacterial cell membrane. The concluding experiment, which was done to establish this 'glucose-permease' inhibition by erythrose, was to study the uptake of $\left[\alpha-{ }^{14} \mathrm{C}\right]$ methylglucoside in non-growing Vibrio cholerae. This glucoside appears to be transported into bacteria by the same "permease mechanism as is needed for glucose (Cohen \& Monod, 1957) and so the rate of uptake of $\alpha$-methylglucoside by bacteria can be used as an indirect measure of the 'glucosepermease' activity of an organism. It was very interesting to note that erythrose caused $70 \%$ inhibition of the uptake of $\alpha$-methylglucoside (Table 5). This inhibition of $\alpha$ methylglucoside uptake confirms the mode of inhibition by this four-carbon sugar on $V$. cholerae to be on the permeation of glucose into the organism.

Recently Együd \& Szent-Györgyi (1966a) reported that methylglyoxal, a ketoaldehyde, inhibits strongly the growth of Escherichia coli as well as the synthesis of protein in the same organism (Együd \& Szent-Györgyi, I966b). The inhibition of protein synthesis by methylglyoxal can be reversed by the addition of cysteine (Együd \& SzentGyörgyi, I966b). Szent-Györgyi, Együd \& McLaughlin (1967) suggested that the methylglyoxal inhibition could be due to a stoichiometric reaction between the ketone aldehyde and certain sulphydryl groups and the reversal by cysteine could be due to regeneration of these sulphydryl groups. In our system, growth inhibition by erythrose could be due to an interaction between the four-carbon sugar and sulphydryl groups, of the gluco-permease of Vibrio cholerae and the reversal by cysteine could be due to the regeneration of these groups.

In conclusion, it may be said that erythrose primarily inhibits the glucose uptake by Vibrio cholerae, which, secondarily, leads to the inhibition of growth of this organism.

We are grateful to Professor B. L. Horecker for helpful suggestions when he visited us, and to Mr Sudhir C. Das for technical assistance.

\section{REFERENCES}

Bhattacharya, P. K., Roy Chowdhury, J. \& Datta, A. G. (1965). Studies on the inhibitory effect of erythrose on the development of experimental cholera. British Medical Journal ii, I35I.

Bollenback, G. N. (1963). Glycosidation. In Methods in Carbohydrate Chemistry. Edited by R. L. Whistler and M. L. Wolfrom, vol. 2, p. 236. New York and London: Academic Press.

CoHen, N. G. \& Monod, J. (1957). Bacterial permeases. Bacteriological Reviews 2I, I69.

EgyüD, L. G. \& SZentT-GyörgYI, A. (I966a). Cell division, SH, ketoaldehydes and cancer. Proceedings of the National Academy of Sciences of the United States of America 55, 388.

Együd, L. G. \& Szent-GyörgYi, A. (1966 b). On the regulation of cell division. Proceedings of the National Academy of Sciences of the United States of America 56, 203.

Finkelstein, R. A. \& Lankford, C. E. (1955). Bacteriological Proceedings 1955, 49.

Fluharty, A. L. \& Ballou, C. E. (I959). D-Threose 2,4-diphosphate inhibition of D-glyceraldehyde 3-phosphate dehydrogenase. Journal of Biological Chemistry 234, 2517.

Grazi, E. A., De Flora, A. \& Pontremoli, S. (1960). The inhibition of phosphoglucose isomerase by D-erythrose-4-phosphate. Biochemical and Biophysical Research Communications 2, I 21.

KornberG, A. \& Horecker, B. L. (1955). Glucose-6-phosphate dehydrogenase. Methods in Enzymology I, 323 .

Lowry, O. H., Rosebrough, N. J., Farr, A. L. \& Randall, R. J. (I95I). Protein measurement with Folin phenol reagent. Journal of Biological Chemistry 193, 265. 
RACKER, E. (1947). Spectrophotometric measurement of hexokinase and phosphohexokinase activity. Journal of Biological Chemistry 167, 843.

Racker, E., Klybas, V. \& Schramm, M. (I959). Tetrose diphosphate, a specific inhibitor of glyceraldehyde 3-phosphate dehydrogenase. Journal of Biological Chemistry 234, 2510.

Roy Chowdhury, J. \& DatTA, A. G. (1965). Studies on the growth inhibitory effect of erythrose on Vibrio cholerae. Biochimica et Biophysica Acta 104, 296.

Slein, M. W. (1955). Phosphohexoisomerases from muscle. Methods in Enzymology I, 209.

Szent-Györgyi, A., Együd, L. D. \& McLaughurn, J. A. (I967). Ketoaldehydes and cell division. Science, New York 155, 539.

Umbreit, W. W., Burris, R. H. \& Stauffer, J. F. (1959). In Manometric Techniques. Burgess: Minneapolis.

Venkataraman, R. \& Racker, E. (196I). Mechanism of action of transaldolase. Journal of Biological Chemistry 236, 1876 . 